\title{
Pengaruh Penerapan Pembelajaran Kooperatif Tipe Jigsaw terhadap Perilaku Kesehatan dan Keselamatan Anak
}

\author{
Ni Made Ayu Suryaningsih ${ }^{\varpi_{1}}$, Christiani Endah Poerwati ${ }^{2}$ \\ Pendidikan Guru Pendidikan Anak Usia Dini, Universitas Dhyana Pura, Bali \\ DOI: $\underline{10.31004 / \text { obsesi.v5i2.751 }}$
}

\begin{abstract}
Abstrak
Penelitian ini bertujuan untuk mengetahui pengaruh penerapan pembelajaran kooperatif tipe jigsaw terhadap perilaku kesehatan dan keselamatan anak usia dini. Jenis penelitian ini adalah quasi eksperiment, dengan rancangan posttest only control group design. Populasi yang digunakan adalah anak usia dini di Kecamatan Kuta Utara. Penentuan kelas kontrol dan kelas eksperimen digunakan sistem random. Pengumpulan data dilakukan dengan observasi menggunakan (google form). Teknik analisa yang digunakan dalam penelitian ini adalah analisis varians (anava) satu jalur. Hasil penelitian menunjukan bahwa terdapat perbedaan perilaku kesehatan dan keselamatan antara anak yang belajar melalui pembelajaran kooperatif tipe jigsaw dengan anak yang belajar melalui model pembelajaran Konvensional. Dapat disimpulkan bahwa terdapat perbedaan yang signifikan terhadap Perilaku Kesehatan dan Keselamatan Anak Usia Dini pada Penerapan Pembelajaran Kooperatif Tipe Jigsaw dibandingkan dengan pembelajaran konvensional. Sehingga diperoleh suatu desain pembelajaran yang efektif dalam meningkatkan perilaku kesehatan dan keselamatan anak usia dini.

Kata Kunci : anak usia dini; perilaku kesehatan dan keselamatan; pembelajaran kooperatif tipe jigsaw
\end{abstract}

\begin{abstract}
This study aims to determine the effect of the application of the type of jigsaw cooperative learning on health and safety behavior of early childhood. This type of research is a quasiexperimental, with a posttest only control group design. The population used is early childhood in North Kuta District. Determination of the control class and experimental class used a random system. Data collection was carried out by observation using (google form). The analysis technique used in this research is one-way analysis of variance (ANOVA). The results showed that there were differences in health and safety behavior between children who learned through jigsaw-type cooperative learning and children who learned through conventional learning models. It can be concluded that there are significant differences in the Health and Safety Behavior of Early Childhood in the Application of Jigsaw-Type Cooperative Learning compared to conventional learning. So that we get an effective learning design in improving health and safety behavior of early childhood..
\end{abstract}

Keywords: early childhood; health and safety behavior; jigsaw cooperative learning.

Copyright (c) 2019 Ni Made Ayu Suryaningsih, \& Christiani Endah Poerwati

$\triangle$ Corresponding author:

Email Address : 1suryaningsih@undhirabali.ac.id (Br. Pegongan, Abiansemal, Badung, Bali)

Received 8 September 2020, Accepted 20 September 2020, Published 2 Oktober 2020 


\section{PENDAHULUAN}

Pembangunan manusia unggul menjadi prioritas utama pembangunan agar tercapai Indonesia Maju. Indikator yang digunakan untuk mengukur sejauh mana keberhasilan pembangunan kualitas hidup manusia adalah Indeks Pembangunan Manusia (IPM). Sebagai ukuran kualitas hidup, IPM dibangun melalui pendekatan tiga dimensi dasar, atau dikenal juga sebagai komponen pembentuk IPM, yaitu umur panjang dan hidup sehat (a long and healthy life), pengetahuan (knowledge), dan standar hidup layak (decent standard of living) (Styawan, 2019). Pendidikan memegang peranan yang sangat penting dalam pengembangan kualitas sumber daya manusia (SDM). Pada program pembangunan nasional, pengembangan di bidang pendidikan menjadi perhatian penting, demi tercapainya peningkatan kualitas sumber daya manusia. Pendidikan memiliki kaitan yang erat dengan bidang kesehatan. Salah satunya yakni dalam upaya pengenalan dan pembiasaan hidup sehat dapat dilakukan melalui pendidikan.

Bidang pendidikan dan kesehatan menjadi perhatian pemerintah untuk mencapai tujuan tersebut. Sektor pendidikan dan kesehatan merupakan dua dari beberapa faktor yang mempengaruhi pembangunan manusia (Astri, Nikensari and Kuncara W., 2013). Perhatian terhadap pendidikan dimulai dari pendidikan anak usia dini hingga pendidikan tinggi. Perhatian terhadap kualitas kesehatan penerus bangsa dicanangkan bahkan dari dalam kandungan. Mekanisme ini dijalankan secara beriiringan, sinergis dan berkelanjutan. Sehingga akan memberikan dampak yang positif kedepan.

Pendidikan awal berperan penting memberikan dasar atau landasan untuk pendidikan selanjutnya. Laily, Jalal and Karnadi (2019) menyatakan Pendidikan Anak Usia Dini sebagai awal jenjang pendidikan tentu sangat memiliki peran sangat penting yang akan menentukan keberhasilan pada jenjang pendidikan selanjutnya. Proses pendidikan pada tahun-tahun pertama kehidupan ini cukup penting bagi pembangunan dan pendidikan anak. Pendidikan prasekolah sebenarnya adalah proses yang mencakup periode sejak lahir hingga sekolah dasar dan bertujuan untuk mendukung perkembangan anak-anak pada usia ini (Akçay, 2016). Demi menjamin kualitas pelayanan di bidang pendidikan anak usia dini, maka pada Peraturan Menteri Pendidikan Kebudayaan nomor 137 tahun 2014, disusunlah suatu Standar Nasional Pendidikan PAUD. Standar ini menyangkut kriteria tentang pengelolaan dan penyelenggaraan PAUD di seluruh wilayah hukum Negara Kesatuan Republik Indonesia (Kemendikbud, 2014a). Salah satu standar menyebutkan tentang Standar Tingkat Pencapaian Perkembangan Anak. Tingkat Pencapaian Perkembangan Anak merupakan laju pertumbuhan dan perkembangan anak yang dapat dicapai pada rentang usia tertentu. Pertumbuhan anak merupakan pertambahan berat dan tinggi badan yang mencerminkan kondisi kesehatan dan gizi yang mengacu pada panduan pertumbuhan anak dan dipantau menggunakan instrumen yang dikembangkan oleh Kementerian Kesehatan yang meliputi Kartu Menuju Sehat (KMS), Tabel BB/TB, dan alat ukur lingkar kepala (Mushlih et al., 2018). Perkembangan anak merupakan integrasi dari perkembangan aspek nilai agama dan moral, fisik-motorik, kognitif, bahasa, dan sosial-emosional, serta seni (Kemendikbud, 2014a).

Peran lembaga pendidikan dalam usaha menjaga serta meningkatkan kesehatan anak, dapat berupa kegiatan peningkatan kesehatan (promotif), pencegahan penyakit (preventif), penyembuhan penyakit (kuratif), maupun pemulihan penyakit (rehabilitatif) yang dilaksanakan secara menyeluruh terpadu dan berkesinambungan. Upaya pemeliharaan kesehatan anak selama berada di satuan PAUD, tidak hanya dilakukan oleh pendidik saja, melainkan seluruh masyarakat sekolah, tidak terkecuali peran anak itu sendiri (Suryaningsih, Cahaya and Poerwati, 2019). Widayati (Widayati, 2018) mengungkapkan anak usia dini memiliki kerentanan yang tinggi terhadap kecelakaan karena keterbatasan kemampuan kognitif. Pada usia ini, anak berada pada tahapan sensori motorik dan operasional konkret. Pemahaman anak yang terbatas menyebabkan anak kurang dapat mengantisipasi dan mengatasi kondisi bahaya yang muncul. Pembelajaran yang diberikan guru PAUD dalam penyelenggaraan perlindungan anak sangat penting karena pembentukan kepribadian dan 1064 | Jurnal Obsesi : Jurnal Pendidikan Anak Usia Dini, 5(2), 2021 
pengetahuan yang tepat dapat mengurangi kasus penyimpangan anak yang disebabkan oleh ketidaktahuan anak (Roza, Nurhafizah and Yaswinda, 2019).

Perilaku kesehatan dan keselamatan anak penting untuk ditanamkan sejak dini. Terlebih lagi adanya pandemi Covid-19 yang telah menimbulkan keresahan di masyarakat terhadap segala kemungkinan buruk yang dapat terjadi. Sehingga urgensi Penerapan Perilaku hidup bersih dan sehat anak usia dini di tengah pandemi Covid 19 sangat penting untuk dilakukan (Anhusadar and Islamiyah, 2020). Perilaku kesehatan dan keselamatan yang dimaksud sesuai dengan indikator pencapaian perkembangan anak usia dini pada KD 3.4. Mengetahui cara hidup sehat dan 4.4. Mampu menolong diri sendiri untuk hidup sehat (Kemendikbud, 2014b). Namun, untuk merubah kebiasaan atau perilaku sebelumnya, dari yang kurang memperhatikan gizi, kebersihan dan kesehatan menjadi sebaliknya, bukan merupakan hal yang mudah. Untuk itu pembiasaan perilaku kesehatan dan keselamatan penting dilakukan sejak dini, dengan menggunakan pendekatan pembelajaran yang inovatif dan sesuai dengan keadaan ini.

Beralihnya pembelajaran tatap muka ke pembelajaran online merupakan transisi pembelajaran yang dianggap efektif saat ini (Wiresti, 2020). Diperlukan metode pembelajaran inovatif dalam pengenalan upaya pemeliharaan kesehatan pada anak, baik secara langsung maupun tidak langsung, dengan mempertimbangkan situasi terkini. Sehingga diharapkan anak memiliki kesiapan dan kesanggupan untuk menjaga kesehatan dan keselamatan diri sendiri.

Model pembelajaran kooperatif merupakan salah satu model pembelajaran yang dapat diterapkan pada anak usia dini, karena model pembelajaran ini memungkinkan anak berperan aktif dalam kelompok, sesuai dengan perkembangan anak yang merupakan usia berkelompok sehingga anak dapat mengembangkan kemampuan sosial emosionalnya. Menurut Hamdani (2011) model pembelajaran kooperatif adalah rangkaian belajar anak dalam kelompok tertentu untuk mencapai tujuan pembelajaran yang dirumuskan (Hamdani, 2011). Salah satu tipe model pembelajaran kooperatif yang dapat diterapkan pada anak usia dini adalah tipe Jigsaw. Model pembelajaran kooperatif tipe jigsaw memungkinkan diterapakan pada anak usia dini karena pada tipe ini anak dibagi menjadi beberapa kelompok heterogen, baik dalam kemampuan maupun jenis kelaminnya, sehingga sifat kelompok yang terbentuk menjadi sejajar.

Model kooperatif Jigsaw II adalah sebuah model belajar kooperatif yang menitikberatkan pada kerja kelompok anak dalam kelompok kecil (Majid, 2013). Jigsaw tipe II dikembangan oleh Slavin dengan sedikit perbedaan. Dalam belajar kooperatif tipe Jigsaw II, secara umum anak dikelompokkan oleh secara heterogen dalam kemampuan Langkahlangkah pembelajaran dengan Jigsaw II dan juga digunakan oleh peneliti antara lain (Trianto, 2011);1) Orientasi. Pendidik menyampaiakan tujuan pembelajaran yang akan diberikan. Memberikan penekanan tentang manfaat penggunaan metode Jigsaw II dalam proses belajar mengajar. Mengingatkan senantiasa percaya diri, kritis dan kooperatif dalam model pembelajaran ini. 2) Pengelompokan. Pembentukan kelompok yang heterogen dari segi kemampuan. 3) Pembentukan dan pembinaan kelompok ahli. Selanjutnya grup itu dipecah menjadi kelompok yang akan mempelajari materi yang diberikan dan dibina supaya jadi ahli, berdasarkan indeksnya. Setiap kelompok diharapkan bisa belajar topik yang diberikan dengan sebaik-baiknya sebelum ia kembali ke dalam grup sebagai tim ahli, tentunya peran pendidik cukup penting dalam fase ini. 4) Diskusi (pemaparan) kelompok ahli dalam grup. Serta 5) Tes (Penilaian) Pada fase ini guru memberikan tes tulis untuk dikerjakan oleh anak yang memuat seluruh konsep yang didiskusikan. Pada tes ini anak tidak diperkenankan untuk bekerjasama.

Pembelajaran kooperatif tipe Jigsaw cukup efektif diterapkan pada pendidikan anak usia dini. Hal ini sesuai dengan beberapa temuan peneliti sebelumnya. Dalam penelitian yang berjudul "Implementation of Cooperative Learning Model in Preschool" menghasilkan temuan "As a result of the obtained data, it has been determined that jigsaw method, one of the cooperative learning 
model,s is more effective in teaching the sense organs subject to the children compared to the traditional teaching method " (Akçay, 2016). Hasil penelitian lain menyebutkan bahwa Model Pembelajaran Cooperative Learning Tipe jigsaw berbantuan media kartu angka bergambar efektif dalam meningkatkan perkembangan kognitif anak TK Widhya Brata Mengwi (Sumyadewi, Ni Luh, 2014). Penelitian dari Poerwati, menyebukan hal yang senada, bahwa model pembelajaran kooperatif tipe jigsaw II berbantuan benda konkret merupakan salah satu alternatif metode pembelajaran yang kreatif, inovatif dan efektif dalam meningkatkan kemampuan matematika anak usia dini (Poerwati, Suryaningsih and Cahaya, 2020). Selain itu Model Pembelajaran Kooperatif Tipe Jigsaw Berbantuan Mind Mapping juga memberikan pengaruh terhadap Keterampilan Berbicara (Febiyanti, Wibawa and Arini, 2020).

Model pembelajaran konvensional merupakan model pembelajaran yang biasa digunakan oleh guru. Pembelajaran ini disebut konvensional karena yang lazim atau sudah biasa diterapkan, seperti kegiatan sehari-hari di kelas oleh guru. Desain pembelajaran bersifat linear dan dirancang part to whole". Menurut Ahmadi dalam (Widiantari, 2012) "model pembelajaran konvensional menyandarkan pada hafalan belaka, penyampain informasi lebih banyak dilakukan oleh guru, siswa secara pasif menerima informasi, pembelajaran sangat abstrak dan teoritis serta tidak bersadar pada realitas kehidupan, memberikan hanya tumpukan beragam informasi kepada siswa, cenderung fokus pada bidang tertentu, waktu belajar siswa sebagaian besar digunakan untuk mengerjakan buku tugas, mendengar ceramah guru, dan mengisi latihan (kerja individual)". Oleh karena itu peran guru dibutuhkan dalam mendesain pembelajaran. Kusnilawati et al. (2018) menyatakan peran guru sangat penting dalam pendidikan anak usia dini dirumah maupun di sekolah merupakan basis utama pendidikan anak.

Berdasarkan latar belakang tersebut peneliti mengkaji pengaruh penerapan pembelajaran kooperatif tipe jigsaw terhadap perilaku kesehatan dan keselamatan pada anak usia dini. Dengan membandingkannya dengan penerapan pembelajaran konvensional.

\section{METODOLOGI}

Penelitian ini merupakan penelitian eksperimen yang meneliti hubungan sebab akibat dengan memanipulasi satu atau lebih variabel pada satu atau lebih kelompok eksperimental. Hasil yang diperoleh kemudian dibandingkan dengan kelompok kontrol. Penelitian ini dilaksanakan di suatu institusi sekolah sehingga secara teknis tidak memungkinkan untuk mengontrol semua variabel secara ketat (full randomize). Oleh sebab itu, penelitian ini tergolong penelitian eksperimen semu (quasi eksperiment). Rancangan penelitian tertera seperti Gambar 1.

\begin{tabular}{|lll|}
\hline $\mathrm{R}$ & $\mathrm{X}_{1}$ & $\mathrm{O}$ \\
$\mathrm{R}$ & $\mathrm{X}_{2}$ & $\mathrm{O}$ \\
\hline
\end{tabular}

\section{Gambar 1 Rancangan Penelitian} Sumber (Sugiyono, 2017)

Keterangan:

$\mathrm{X}_{1}=$ Pembelajaran kooperatif tipe jigsaw

$\mathrm{X}_{2}=$ Pembelajaran dengan Model pembelajaran konvensional

$\mathrm{O}=$ Pengamatan Akhir berupa observasi perilaku kesehatan dan keselamatan

Populasi penelitian ini adalan seluruh anak usia dini di kelompok B, di TK Tunas Mekar II Dalung yang berjumlah 57 anak yang tersebar dalam 3 kelas. Penentuan sampel pada penelitian ini dilakukan dengan metode group random sampling. Sehingga diperoleh kelas B2 sebagai kelas kontrol yang berjumlah 18 anak dan kelas B3 yang berjumlah 18 anak sebagai kelas eksperimen. 
Variabel bebas yang digunakan dalam penelitian ini yakni model pembelajaran, yang meliputi model pembelajaran kooperatif tipe jigsaw dan konvensional. Variabel terikat dalam penelitian ini adalah Perilaku kesehatan dan keselamatan pada anak usia dini. Hubungan antarvariabel penelitian ditunjukkan oleh Gambar 2.

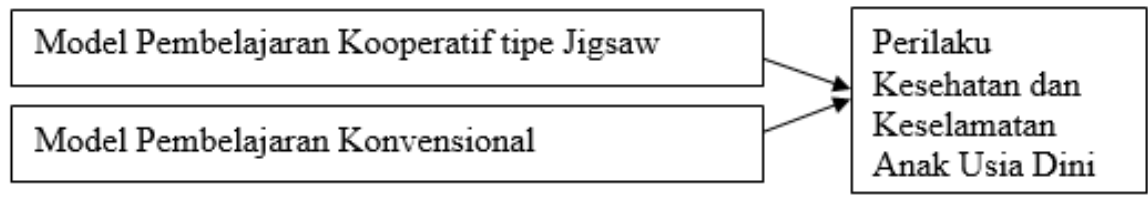

Gambar 2 Hubungan antara Variabel-Variabel Penelitian

Pengumpulan data dalam penelitian ini dilakukan dengan metode observasi menggunakan lembar observasi pada google form tentang perilaku kesehatan dan keselamatan pada anak usia dini baik kelas eksperimen maupun kelas kontrol. Proses pembelajaran juga dilakukan dalam jaringan (Daring) melalui media Zoom Clouds Meeting, mengingat penelitian ini dilaksanakan pada masa pandemi Covid-19.

Instrumen yang digunakan dalam penelitian ini berupa lembar observasi perilaku kesehatan dan keselamatan anak usia dini dengan penskoran menggunakan skala Likert, dengan degradasi mulai dari: sangat kurang, kurang, cukup, baik, dan sangat baik. Pembuatan indikator pada lembar observasi didasari oleh Permendikbud No. 146 tahun 2014 (Kemendikbud, 2014b).

Uji hipotesis dalam penelitian ini untuk mengetahui adanya pebedaan yang signifikan antara perilaku kesehatan dan keselamatan dengan menggunakan pendekatan pembelajaran masyarakat belajar dibandingkan dengan pembelajaran konvensional pada anak usia dini. Teknik analisis data yang digunakan untuk menganalisis data hasil penelitian adalah analisis varians (anava) satu jalur yang melibatkan satu variabel bebas dan satu variabel terikat (Sugiyono, 2017). Sebelum dilaksanakan uji hipotesis penelitian, data yang akan diolah dengan teknik anava harus memenuhi asumsi prasyarat analisis, yakni homogen dan terdistribusi normal.

\section{HASIL DAN PEMBAHASAN}

Sebelum dilakukan uji hipotesis melalui metode statistika dengan formula ANAVA satu jalur, hasil post test perilaku kesehatan dan keselamatan anak usia dini terlebih dahulu harus memenuhi uji prasyarat. Adapun Uji prasyarat yang dilakukan adalah uji normalitas, dan uji homogenitas varians. Uji normalitas dilakukan untuk mengetahui apakah sebaran frekuensi data setiap variabel berdistribusi normal atau tidak. Uji normalitas dalam penelitian ini menggunakan bantuan program SPSS 21.0 for windows dengan menggunakan lajur Kolmogorov-Smirnov dan Shapiro-Wilk. Kriteria yang diapakai adalah jika nilai signifikansi > 0,05 maka datanya berdistribusi normal, sebaliknya jika nilai signifikansi $<0,05$ datanya tidak berdistribusi normal. Berikut ini disajikan tabel 1 hasil uji normalitas data penelitian.

Tabel 1 Rekapitulasi Hasil Uji Normalitas Data Tests of Normality

\begin{tabular}{lrrrrrrr}
\hline & \multicolumn{2}{c}{ Kolmogorov-Smirnov $^{\text {a }}$} & \multicolumn{4}{c}{ Shapiro-Wilk } \\
& Statistic & df & \multicolumn{1}{c}{ Sig. } & Statistic & df & \multicolumn{1}{c}{ Sig. } \\
\hline B3 &, 183 & 18 &, 114 &, 901 & 18 &, 059 \\
B2 &, 180 & 18 &, 126 &, 907 & 18 &, 076 \\
\hline
\end{tabular}

a. Lilliefors Significance Correction

Berdasarkan hasil uji normalitas pada Tabel 1, di atas dapat diketahui bahwa data tersebar normal untuk semua unit analisis, baik pada kelas kontrol maupun eksperimen. Hal tersebut ditunjukan oleh nilai signifikansi pada uji statistic Kolmogorov-Smirnov maupun 
Shapiro-Wilk, yang menunjukan nilai signifikansi lebih besar dari 0,05. Dapat dikatakan bahwa skor perilaku kesehatan dan keselamatan pada anak usia dini pada kelas kontrol maupun kelas eksperimen berdistribusi normal.

Pengujian homogenitas dilakukan dengan uji Levene's Test of Equality of Error Variances (Levene's Test) yang dianalisis dengan menggunakan program SPSS 21 for windows. Data dikatakan memiliki varian yang sama jika angka signifikansinya lebih besar dari 0,05. Berikut pada Tabel 2 disajikan hasil uji homogenitas varian data.

Tabel 2 Hasil Uji Homogenitas Data

Test of Homogeneity of Variances

Perilaku Kesehatan dan Keselamatan

\begin{tabular}{cccccc}
\hline Levene Statistic & df1 & & df2 & Sig. \\
\hline 1,456 & & 1 & & 34 &, 236 \\
\hline
\end{tabular}

Berdasarkan data pada tabel 2, diperoleh hasil angka signifikansi sebesar 0,236, lebih besar dibandingkan 0,05. Hal tersebut berarti bahwa data perilaku kesehatan dan keselamatan pada anak usia dini memiliki sebaran data yang homogen.

Berdasarkan uji prasyarat, ditemukan bahwa data yang diperoleh berdistribusi normal, dan memiliki varian data homogen. Tahap selanjutnya dilakukan pengujian hipotesis menggunakan Analisis Univariat (ANAVA). Pengujian hipotesis dilakukan dengan bantuan program SPSS 21 for windows. Data yang diperoleh disajikan pada Tabel 3.

Tabel 3. Hasil Analisis Menggunakan ANAVA Satu Jalur

Perilaku Kesehatan dan Keselamatan

\begin{tabular}{|c|c|c|c|c|c|}
\hline & $\begin{array}{l}\text { Sum of } \\
\text { Squares }\end{array}$ & $\mathrm{df}$ & Mean Square & $\mathrm{F}$ & Sig. \\
\hline Between Groups & 49,000 & 1 & 49,000 & 4,332 & , 045 \\
\hline Within Groups & 384,556 & 34 & 11,310 & & \\
\hline Total & 433,556 & 35 & & & \\
\hline
\end{tabular}

Berdasarkan tabel 3 diperoleh taraf signifikansi 0,045 ( $p<0,05)$. Dengan demikian dapat disimpulkan bahwa hipotesis alternative yang menyatakan "terdapat perbedaan hasil perilaku kesehatan dan keselamatan pada anak usia dini yang belajar melalui pembelajaran kooperatif tipe jigsaw dengan anak yang belajar melalui model pembelajaran konvensional" diterima.

Pada hasil Uji ANAVA sebelumnya, menyatakan bahwa secara signifikan terdapat perbedaan perilaku kesehatan dan keselamatan pada anak usia dini yang mengikuti pembelajaran kooperatif tipe jigsaw dengan anak yang mengikuti pembelajaran konvensional. Berdasarkan hasil pengujian hipotesis terlihat bahwa hipotesis alternatif yang diajukan telah berhasil menolak hipotesis nol yang menyatakan tidak ada perbedaan perilaku kesehatan dan keselamatan anak usia dini menggunakan pembelajaran kooperatif tipe jigsaw dengan menggunakan metode konvensional. Disimpulkan bahwa menggunakan pembelajaran kooperatif tipe jigsaw lebih baik dibandingkan dengan metode konvensional dalam meningkatkan perilaku kesehatan dan keselamatan anak usia dini.

Berikut diikthisarkan pada tabel 4 tentang hasil observasi rata-rata pemahaman konsep matematika pada anak usia dini menggunakan pendekatan masyarakat belajar serta menggunakan metode konvensional

Tabel 4 Perbandingan Rerata Skor Perilaku Kesehatan dan Keselamatan Anak Usia Dini

\begin{tabular}{cc}
\hline Kelas Eksperimen & Kelas Kontrol \\
\hline $\mathbf{N}=\mathbf{1 8}$ & $\mathrm{N}=18$ \\
$\bar{X}=\mathbf{2 0 , 2 7 8}$ & $\bar{X}=17,95$
\end{tabular}

1068 | Jurnal Obsesi : Jurnal Pendidikan Anak Usia Dini, 5(2), 2021 

DOI: 10.31004/obsesi.v5i2.751

Berdasarkan tabel 4, mengenai perbandingan rerata skor perilaku kesehatan dan keselamatan anak usia dini, maka dapat digambarkan dalam grafik berikut.

Rata-rata Perilaku Kesehatan dan Keselamatan

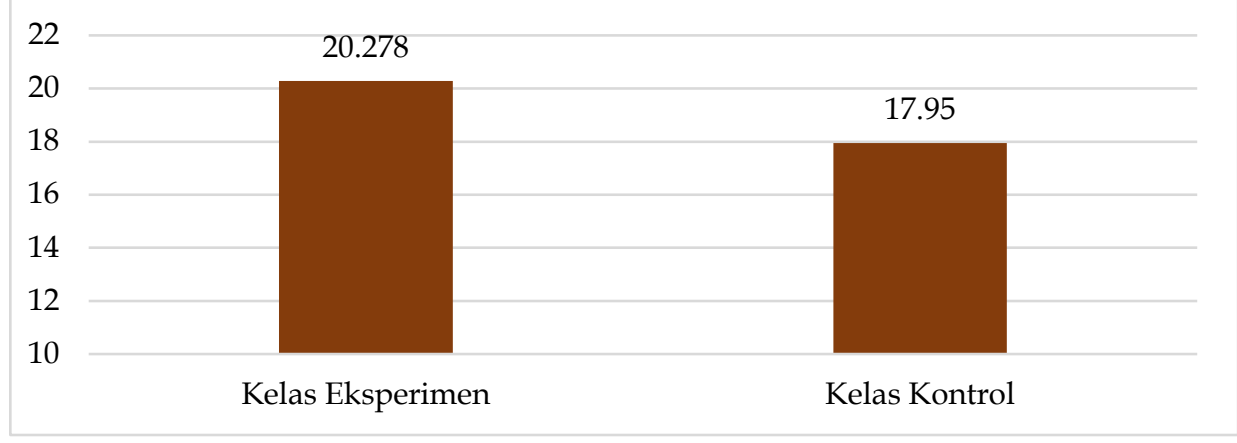

Gambar 1. Perbandingan Rerata Skor Kelas Eksperimen dan Kelas Kontrol

Temuan empiris seperti yang tertera pada hasil analisis deskriptif perilaku kesehatan dan keselamatan anak usia dini menunjukkan bahwa anak pada kelas yang belajar dengan pembelajaran kooperatif tipe jigsaw berada pada kualifikasi berkembang sangat baik dan kelas yang belajar dengan pembelajaran konvensional berada pada kategori yang berkembang sesuai harapan. Jika dibandingkan berdasarkan skor rata-rata yang terdapat pada tabel 4, siswa kelompok eksperimen (pembelajaran kooperatif tipe jigsaw) memperoleh rata-rata 20,278 dan siswa kelompok kontrol (Pendekatan Konvensional) memperoleh rata-rata 17,95.

Secara teoritis, pembelajaran kooperatif merupakan proses belajar mengajar dengan menggunakan pendekatan yang berpusat pada kelompok kecil untuk bekerja sama sehingga dapat mencapai tujuan dari proses pembelajaran tersebut (Hambali, 2017). Model pembelajaran kooperatif tipe jigsaw diterapkan dengan cara mengarahkan siswa untuk membentuk kelompok-kelompok kecil yang kemudian anggota dari kelompok tersebut diberikan materi yang berbeda dengan anggota lainnya, sehingga setiap anggota kelompok dapat membantu anggota lainnya untuk memahami dan menguasai materi yang digunakan. Selain itu, jigsaw adalah model yang mengajarkan siswa melalui teman sebaya sehingga dapat menciptakan semangat kerja sama dan menumbuhkan tanggung jawab (Munte, 2019). Hal tersebut akan membuat anggota kelompok berlatih bertanggung jawab untuk menguasai materi yang diberikan kepadanya sehingga dapat menjelaskan ke anggota kelompok lainnya nantinya (Febiyanti, Wibawa and Arini, 2020). Pernyataan pendukung lainnya juga menyatakan bahwa jigsaw mampu membuat siswa mahir dalam suatu materi yang mereka pelajari (Kamaruddin and Yusoff, 2019). Melalui proses diskusi secara daring pada kelompok kecil via Zoom Cloud meeting, maka dibangun pemahaman siswa akan hidup sehat dan bersih, sehingga mengubah pandangan dan cara mereka menerapkan perilaku kesehatan dan keselamatan.

Hasil penelitian ini menunjukan bahwa anak usia dini dapat belajar dan bekerjasama dalam kelompok dengan mengikuti proses diskusi mengenai perilaku kesehatan dan keselamatan dengan pimpinan teman sebaya sebagai tutor. Dalam proses diskusi anak dapat menilai suatu perbuatan atau perilaku yang baik dan buruk dalam menjaga kesehatan, serta dampak yang dapat ditimbulkan. Melalui pembelajaran kooperatif anak belajar membangun tanggung jawab diri sendiri dan anggota kelompoknya melalui suatu kepercayaan atas kemampuan dan bakat mereka, dan saling memberi penghargaan (Mashudi, 2016). Proses diskusi kelompok ini selain dapat meningkatkan pemahaman mengenai perilaku kesehatan dan keselamatan, dapat pula berdampak dalam kemampuan sosial dan interpersonal anak. Hal ini senada dengan penemuan terdahulu yang menyatakan bahwa model pembelajaran 
kooperatif tipe jigsaw juga efektif dalam meningkatkan kemampuan lainnya seperti keterampilan sosial (Wasito, 2017), dan kecerdasan intrapersonal (Fadillah, 2018).

Sedangkan pada kelas kontrol yang menggunakan pendekatan konvensional lebih menekankan bentuk pembelajaran dengan metode ceramah, demostrasi, pelatihan atau praktek secara individual. Pada pendekatan ini peran guru sebagai pemberi informasi, penyampaian pelajaran ditransformasikan langsung oleh guru kepada siswa. Walaupun proses pembelajaran dilakukan secara daring, pada pembelajaran konvensional ini guru mendominasi jalannya pembelajaran (Teacher Centered), sehingga siswa cenderung pasif dan hanya menerima informasi dari guru. Guru berperan sepenuhnya dalam pembelajaran (Cahaya, 2016; Munawaroh, 2017; Hasanah and Muryanti, 2019). Guru akan memberikan penjelasan singkat dan penugasan langsung pada para siswa melalui media WhatsApp group. Kegiatan yang dilakukan siswa selama pembelajaran terjadi hanyalah menyimak, dan mengerjakan tugas.

Berdasarkan deskripsi landasan operasional teoretik tersebut, dapat dipahami bahwa pembelajaran kooperatif tipe jigsaw lebih unggul dibandingkan dengan pendekatan konvensional dalam pencapaian perkembangan perilaku kesehatan dan keselamatan anak usia dini.

\section{SIMPULAN}

Terdapat perbedaan perilaku kesehatan dan keselamatan antara anak yang belajar melalui pembelajaran kooperatif tipe jigsaw dengan anak yang belajar melalui model pembelajaran Konvensional. Dimana ditemukan bahwa anak yang mengikuti proses pembelajaran kooperatif tipe jigsaw lebih unggul dibandingkan dengan pendekatan konvensional dalam pencapaian perkembangan perilaku kesehatan dan keselamatan anak usia dini pada KD 3.4. Mengetahui cara hidup sehat dan 4.4. Mampu menolong diri sendiri untuk hidup sehat. Keterbatasan yang dialami dalam pelaksanaan penelitian ini yakni penyesuaian (adaptasi) anak dalam proses pembelajaran (diskusi kelompok) dalam jaringan (penggunaan aplikasi Zoom Cloud Meeting).

\section{UCAPAN TERIMA KASIH}

Pada kesempatan ini penulis menyampaikan ucapan terima kasih kepada pihak-pihak yang telah banyak memberikan masukan dalam pelaksanaan penelitian ini, yakni ; (1) Kementerian Riset dan Teknologi, Badan Riset dan Inovasi Nasional, Deputi Bidang Penguatan Riset dan Pengembangan yang telah memberikan kesempatan dan mendanai pelaksanaan penelitian ini. (2) Dr. I Gusti Bagus Rai Utama, SE. M.MA., MA. selaku Rektor Universitas Dhyana Pura, yang telah memberikan motivasi dan rekomendasi guna kelancaran pelaksanaan penelitian. (3) Dr. Jaya Pramono, S.Pd., M.Par, selaku Dekan Fakultas Ekonomika dan Humaniora Universitas Dhyana Pura, yang telah banyak masukan dalam pelaksanaan penelitian ini. (4) Putu Chris Susanto, B.A., MBA., M.E selaku Ketua Lembaga Penelitian dan Pengabdian Masyarakat Universitas Dhyana Pura, yang telah banyak memberikan arahan dalam pelaksanaan penelitian ini. Dan (5) I Gusti Ayu Rai Citrawati, S.Pd., selaku Kepala Sekolah TK Tunas Mekar II Dalung yang telah memberikan ijin dalam pelaksanan penelitian ini. Karena dengan bantuan dari pihak-pihak tersebutlah maka penulis dapat melaksanakan penelitian, sesuai dengan yang direncanakan.

\section{DAFTAR PUSTAKA}

Akçay, N. O. (2016) 'Implementation of Cooperative Learning Model in Preschool', Journal of Education and Learning, 5(3), p. 83. doi: 10.5539/jel.v5n3p83.

Anhusadar, L. and Islamiyah, I. (2020) ‘Penerapan Perilaku Hidup Bersih dan Sehat Anak Usia Dini di Tengah Pandemi Covid 19', Jurnal Obsesi : Jurnal Pendidikan Anak Usia Dini, 5(1), p. 463. doi: 10.31004/obsesi.v5i1.555. 
Astri, M., Nikensari, S. I. and Kuncara W., H. (2013) 'Pengaruh pengeluaran pemerintah daerah pada sektor pendidikan dan kesehata terhadap indeks pembangunan manusia di indonesia', Jurnal Pendidikan Ekonomi dan Bisnis (JPEB). Universitas Negeri Jakarta, 1(1), p. 77. doi: 10.21009/jpeb.001.1.5.

Cahaya, I. M. E. (2016) 'Alternatif pembelajaran untuk meningkatkan pemahamankonsep matematika pada anak usia dini', JEPUN | Jurnal Pendidikan Universitas Dhyana Pura, $1(2)$.

Fadillah, S. (2018) 'Pengaruh Strategi Pembelajaran Kooperatif (Cooperatif Learning) dan Kecerdasan Intrapersonal terhadap Perilaku Prososial Anak Usia 5-6 Tahun di Kelurahan Umban Sari Pekanbaru', PAUD Lectura: Jurnal Pendidikan Anak Usia Dini, 2(01), pp. 91-102. doi: 10.31849/paudlectura.v2i01.2008.

Febiyanti, D., Wibawa, I. M. C. and Arini, N. W. (2020) 'Model Pembelajaran Kooperatif Tipe Jigsaw Berbantuan Mind Mapping Berpengaruh terhadap Keterampilan Berbicara', Mimbar Ilmu, 25(2), p. 121. doi: 10.23887/mi.v25i2.26620.

Hambali (2017) 'Cooperatif Learning sebagai Upaya Membangkitkan Kembali Extinction Motivasi Belajar', Jurnal Edureligia, 1(2). doi: 10.33650/edureligia.v1i2.43.

Hamdani (2011) Strategi Belajar Mengajar. Bandung: Pustaka Setia.

Hasanah, A. and Muryanti, E. (2019) 'Pengaruh Penggunaan Media Diorama terhadap Perkembangan Kemampuan Motorik Halus Anak Usia Dini', Aulad: Journal on Early Childhood, 2(2), pp. 1-7. doi: 10.31004/aulad.v2i2.29.

Kamaruddin, S. and Yusoff, N. M. R. N. (2019) 'The Effectiveness of Cooperative Learning Model Jigsaw and Team Games Tournament (TGT) towards Social Skills', Creative Education, 10(12), pp. 2529-2539. doi: 10.4236/ce.2019.1012180.

Kemendikbud (2014a) Permendikbud No 137, 2014. Standar Nasional Pendidikan Anak Usia Dini. Indonesia.

Kemendikbud (2014b) Permendikbud No 146, 2014. Kurikulum 13 Pendidikan Anak Usia Dini. Indonesia.

Kusnilawati, K. et al. (2018) 'Meningkatkan Kemampuan Berbahasa Anak Usia 5-6 Tahun Dengan Penerapan Metode Tanya Jawab', Aulad: Journal on Early Childhood. LPPM Universitas Pahlawan Tuanku Tambusai, Riau, Indonesia, 1(1), pp. 1-7. doi: 10.31004/aulad.v1i1.1.

Laily, A., Jalal, F. and Karnadi, K. (2019) ‘Peningkatan Kemampuan Konsep Matematika Awal Anak Usia 4-5 Tahun melalui Media Papan Semat', Jurnal Obsesi : Jurnal Pendidikan Anak Usia Dini, 3(2), p. 396. doi: 10.31004/obsesi.v3i2.214.

Majid, A. (2013) Strategi Pembelajaran. Bandung: PT Remaja Rosdakarya.

Mashudi, M. (2016) 'Strategi Pembelajaran Kooperatif Tipe Jigsaw Versus Pembelajaran Langsung', UNIVERSUM, 10(2), pp. 149-162. doi: 10.30762/ universum.v10i2.269.

Munawaroh, H. (2017) 'Pengembangan Model Pembelajaran dengan Permainan Tradisional Engklek Sebagai Sarana Stimulasi Perkembangan Anak Usia Dini', Jurnal Obsesi : Jurnal Pendidikan Anak Usia Dini, 1(2), p. 86. doi: 10.31004/obsesi.v1i2.19.

Munte, B. (2019) 'The Effect of Cooperative Model "Jigsaw Type" in Improving Students' Achievement at Christian Education Subject Case: Grade XII IPA 1-2 SMA Negeri 1 Tebing Syahbandar', International Journal of English Literature and Social Sciences, 4(2), pp. 344-350. doi: 10.22161/ijels.4.2.24.

Mushlih, A. et al. (2018) Analisis Kebijakan PAUD Mengungkap Isu-Isu Menarik Seputar AUD. Jawa Tengah: Mangkubumi. Jawa Tengah: Penerbit Mangku Bumi.

Poerwati, C. E., Suryaningsih, N. M. A. and Cahaya, I. M. E. (2020) 'Model Pembelajaran Kooperatif Tipe Jigsaw II dalam Meningkatkan Kemampuan Matematika Anak', Jurnal Obsesi : Jurnal Pendidikan Anak Usia Dini, 5(1), p. 281. doi: 10.31004/obsesi.v5i1.496.

Roza, D., Nurhafizah, N. and Yaswinda, Y. (2019) ‘Urgensi Profesionalisme Guru Pendidikan Anak Usia Dini dalam Penyelenggaraan Perlindungan Anak', Jurnal Obsesi : Jurnal Pendidikan Anak Usia Dini, 4(1), p. 277. doi: 10.31004/obsesi.v4i1.325. 
Styawan, D. (2019) ‘Pembangunan Manusia Indonesia: Capaian dan Tantangan', Kompasiana. Available at: https://www.kompasiana.com/da_styawan/5cc518aacc52833d43362f62/pembangu nan-manusia-indonesia-capaian-dan-tantangan?page=all\#sectionall.

Sugiyono (2017) 'Metode Penelitian Pendidikan: Pendekatan Kuantitatif, Kualitatif, R\&D', Cetakan ke-25. Bandung: CV Alfabeta.

Sumyadewi, Ni Luh, D. (2014) 'Penerapan Model Pembelajaran Cooperative Learning Tipe Jigsaw Berbantuan Media Kartu Angka Bergambar Untuk Meningkatkan Perkembangan Kognitif Anak TK Widhya Brata Mengwi', e-Journal PG-PAUD Universitas Pendidikan Ganesha Jurusan Pendidikan Guru Pendidikan Anak Usia Dini., 2(1).

Suryaningsih, A., Cahaya, I. M. E. and Poerwati, C. E. (2019) 'Implementasi Metode Experiential Learning dalam Menumbuhkan Perilaku Kesehatan dan Keselamatan Anak Usia Dini', Jurnal Obsesi : Jurnal Pendidikan Anak Usia Dini, 4(1), p. 187. doi: 10.31004/obsesi.v4i1.317.

Trianto (2011) Mendesain Model Pembelajaran Inovatif - Progresif. Jakarta: Kencana Prenada Media Group.

Wasito, D. R. H. I. (2017) ‘Efektivitas Pembelajaran Kooperatif (Cooperative Learning) Untuk Meningkatkan Keterampilan Sosial Pada Siswa Taman Kanak-Kanak', Jurnal Psikologi Ulayat, 4(2), pp. 160-174. doi: 10.24854/jpu22017-101.

Widayati, T. (2018) 'Pendidikan Keselamatan diri Anak Usia Dini (Studi Kasus di Kelompok Bermain (KB) Gaharu Plus Kutai Kartanegara)', Jurnal Ilmiah VISI PGTK PAUD dan Dikmas, 13(2), pp. 113-122. doi: 10.21009/JIV.1302.5.

Widiantari (2012) Model Pembelajaran Konvensional. Bandung: Pustaka Setia.

Wiresti, R. D. (2020) 'Analisis Dampak Work From Home pada Anak Usia Dini di Masa Pandemi Covid-19', Jurnal Obsesi : Jurnal Pendidikan Anak Usia Dini, 5(1), p. 641. doi: 10.31004/obsesi.v5i1.563. 